\title{
Similes in Thomas Hardy's Tess of the D'Urbervilles and their Translation into Albanian
}

\section{Leonard Rapi}

\author{
Department of Foreign Languages, Faculty of Social Sciences and Education \\ University of Gjirokastër, "Eqrem Çabej" Albania \\ nardirapi@yahoo.com
}

Harallamb Miçoni

Faculty of Social Sciences and Education, Department of Foreign Languages University of Gjirokastër, "Eqrem Çabej" Albania

Doi:10.5901/jesr.2014.v4n4p270

miconisllambi@yahoo.gr

\begin{abstract}
This paper aims to investigate similes in Thomas Hardy's novel Tess of the d'Urbervilles and their translation into Albanian. Similes will first be analyzed in terms of their structural make up. The next step will be the analysis of their semantic content and the stylistic functions they fulfill in the original text followed by the way they have been recreated in the text in Albanian. The overall aim of the paper is to shed some light on the way these rhetorical tropes are dealt with in translation.
\end{abstract}

Keywords: similes, comparison markers, semantic content, stylistic aspects, translation strategies

\section{Introduction}

This paper investigates similes in Tess of the d'Urbervilles, a novel by the $19^{\text {th }}$ century British author Thomas Hardy and their translation into Albanian. By simile we mean the 'word or phrase that compares something to something else, using words like or as, for example, a face like a mask (OALD, 2008). In this category we include mainly ad hoc expressions created by authors for the artistic needs of their literary works. However, we do not exclude the similes which, through frequent use, have become part of the language and as such appear as special entries in dictionaries.

Similes in the source text are first analyzed in terms of their structural make up. What is intended here is a brief presentation and categorization of the similes according to their comparison marker. Next their semantic - stylistic features are examined. Finally, similes in the source text are compared and contrasted with their respective translations in the target text whereby we try to identify similarities and/or differences between them as well as features of the translator's style in dealing with the translation of similes from English into Albanian.

\section{Theoretical Discussion}

\subsection{Similes and their function}

Definitions of similes converge in that they are generally seen as associations between entities belonging to different conceptual domains. For instance, Pierini (2007) defines similes as the statement of similarity that exists between two entities in at least one aspect. For Harris (2010) similes are comparisons between two different things that resemble each other in at least one way. Similes are structurally organized in three components. The first is the entity that is being described. The second is the comparison marker which establishes the relationship between the constituent entities, and the third is the constituent serving as the descriptor.

According to Fromilhague (1995 cited in Pierini 2007), similes serve a dual purpose. Apart from being concise and efficient means of communication, they are also employed cognitively to perceive things in new, unexpected ways depending on the type of discourse and text in which they occur. In scientific discourse, for example, they are used to exemplify and clarify. In argumentation similes can clarify and explain. They can also be found in school texts with the aim of facilitating learning by explaining difficult, abstract concepts through concrete, easy to grasp concepts. Similes abound in literary texts where they are widely employed as creative ways of seeing things in new, unusual ways. 


\subsection{Issues of translation}

Despite the fact that similes are one of the most frequently occurring rhetorical means, often surpassing even metaphors or idiomatic expressions, when it comes to their translation, they are still one of the least researched items. Because they have traditionally been considered as a weaker form of metaphor, the translation strategies that are usually employed for the translation of metaphor are also applied to the translation of similes. The case in point is Pierini $(2007,31)$ who borrows Newmark's (1981) scheme which he sets out for metaphor translation.

S1: literal translation (retention of the same vehicle)

S2: replacement of the vehicle with a different vehicle

S3: reduction of the simile, if idiomatic, to its sense

S4: retention of the same vehicle plus explicitation of similarity feature(s)

S5: replacement of the vehicle with a gloss

S6: omission of the simile

While we do not object to this point, we hold the view that while basically a semantic rhetorical trope, the syntactic aspect is of special importance in similes. For this reason, we agree with Tsõmbarevitš $(2011,17)$, who states that in the process of simile translation, it is necessary to keep an eye on the structural elements of the simile and that the translator should try to strike the right balance between the semantic content and syntactic form because it is only by transferring the simile's three constituents that the simile will be preserved both semantically and syntactically. This is also the premise that will guide our research process.

\section{Methodology}

Our method of study is an empirical, inductive one. The data come from Thomas Hardy's novel Tess of the d'Urbervilles and its translation into Albanian Tesi i d'Erbervileve. The first step to the investigation of similes was the identification of the similes in the source text and their mapping on to their translations in the target text. Next, the similes were examined in terms of their comparison markers and their semantic content. Finally, they were compared and contrasted with their translations with the view to discovering possible patterns of translations.

\section{Analysis of the Results}

\subsection{Similes according to their comparison marker}

The comparison marker is the linguistic means which not only signals similes, but also establishes the relationship between their constituents. According to the comparison marker, similes in Tess of the d'Urbervilles fall into five types:

1. Similes with like. These constitute the largest group with 86 instances.

e.g., like a map beneath him (p.6), like a weaver's shuttle (p.15), like a raging tiger (p.25), like an arrow (p.28), like a sword (p.28), like a geranium bloom (p.33), like a bather about to make his plunge (p.35), like one in a dream (f.37), like a painter from his easel (p.46), like those of a wild animal (p.52), like Impatience on a monument (p.58), like a nimbus of a saint (p.63), like a Chinaman's queue (p.66)

2. Similes with as. There are 24 instances.

e.g., as the sap in the twigs (p.102), as the one soothing thing within the dusky horizon (p.323), as one in a dream (p.344), as the faeces of the same buzzing red glutton (p.345), as of Pandemonium (p.347), as Abraham might have mourned over Isaac while they went up the hill together (p.351), as the voice of the cuckoo in the third week (p.372), as a shining light (p.400), as in an isometric drawing. (p.413)

3. Similes with as....as with 27 instances. These similes have the following structure:

1. as + adjective/adverb + noun/noun phrase

2. - + adjective/adverb + noun/noun phrase

e.g., as sumple as a duchess's (p.22), as dignified as Chapels-of-Ease (p.34), as luminous and beautiful as some Praxitelean creation (p.67), sensitive as a gossamer, and blank as snow (p.74), rapid as the shadow of a cloud (p.105), as dazzling as that of cultivated flowers (p.126), stealthily as a cat (p.126), as surely as two streams in one vale (p.132), rotten as touch-wood (p.136), as unnatural and ghastly as a laugh in hell (p.235), as white as the scene without (p.303), heavy and thick as a warrior's (p.343)

4. Similes with as if/though. There are 16 instances.

e.g., as if they were a pair of eyes in the small of his back (p.89), as if it had been a snake's (p.173), as if they had 
put off a vegetable for an animal integument. (p.297), as if you'd been had-rode (p.339), as if they were a quarter of a mile off, ( $p .42)$, as if they were silvered (p.413), as if in prayer ( $p .414)$

5. Noun-like similes. These similes are placed before nouns and function as adjectives. 8 instances have been counted.

e.g., lath-like stripling (p.4), cliff-like dwellings (p.47), business-like tones (p.112), the wave-like curl of her lashes (p.130), moon-like eyes (f.135), dream-like fixity (p.154), a pumpkin-like moon (p.182), tower-like pillar (p.409)

\subsection{Semantic features of similes}

In order to shed light on some of the semantic-stylistic features of similes, they were analyzed in terms of the lexical fields to which their descriptive component belongs. The lexical field with the largest number of instances is that consisting of lexical items denoting animals, birds or insects. For instance:

like a raging tiger ( $p .25)$, like those of a wild animal, like a slimy snake ( $p .66)$, like the love making of a grasshopper (p.89), like a long dog (f.113), like a fascinated bird (p.125), stealthily as a cat (p.126), like pigeons (p.146), as if it had been a snake's (p.173), warm as a sunned cat (p.174), like the skim of a bird (p.200), waiting like wolves (p.200), like a bird in a springe (p.201), as a bled calf (p.347), as the voice of the cuckoo (p.372)

What can be noticed is that the descriptive components denote species that are commonly found in rural settings like those depicted by Hardy. The figures of the animals often carry specific symbolism and are employed to express a large variety of notions. For example, comparison to birds, symbols of fragility and delicacy, is meant to further emphasize these qualities in Tess or other female characters. In popular culture, the wolf is often associated with qualities like aggressiveness or ferociousness. In the specific context of the novel it symbolizes Tess's bitter past, which is said to be in constant attack in order to dominate her fragile spiritual state. The comparison to the cat, stealthy as a cat, is built on the cat's physical quality of elasticity that allows it to enter places unnoticed. A newly born calf in as a bled calf conveys the idea of powerlessness. In general, the lexical items used as descriptive elements are used for what they are usually perceived in the British culture. An exception to this would be the symbol of the snake. There are two instances of similes with the word snake as descriptor. In contrast to its usually negative image, the emotional charge is neutral in like a slimy snake, where the emphasis is on its physical ability to crawl, whereas in as if it had been a snake's it is positive as it refers to Tess's mouth.

Another lexical field is that consisting of lexical items that denote plants.

like a geranium bloom (p.33) as the skin of mushrooms (p.79) as the sap in the twigs (p.102), as dazzling as that of cultivated flowers (p.126), like a plant in too burning a sun (p.174), as a new-gathered mushroom (p.180), as that wild convolvulus (f.181), a pumpkin-like moon (p.182), like a lotus-headed column (p.244), like a full-blown jonquil (p.361), like a half-opened flower (p.405)

These similes build on various physical peculiarities of plants. Firstly, it is the colour. The d'Urbervilles villa built of red bricks is said to look like a geranium bloom in strong contrast to the surrounding dark background. Jupiter, the star in the sky, is as bright as a full-blown jonquil. The exuberant vegetation is as colorful as a cultivated garden. The texture is another feature used to compare humans to plants. The outer layer of a mushroom is used on at least two occasions to describe Tess's skin to emphasize its softness. The shape of the flowers or plants is also employed with a view to depicting various things or objects. For instance, the smoke coming out of the chimney is likened to a lotus, a special kind of lily, or the moon acquires the form of a pumpkin. Apart from the simile with the snake which we mentioned above, Tess's mouth when she sleeps is also likened to a half-opened flower conveying an idea of beauty combined with freshness. In general these similes are qualitative. Although they are fewer in number, there are also similes that are built quantitatively. A case in point is I am sure Tess has as many experiences as that wild convolvulus. It is uttered by Angel Claire and is meant to refer to his belief in the girl's purity of character due to her lack of life experience.

Biblical elements constitute a rich lexical layer in the novel. They occur in Hardy's authorial comments as well as in the language of the characters. Getting to know Angel Claire, Tess grows acutely aware of her own intellectual deficiencies and in a moment of self-pity she says "I'm like the poor Queen of Sheba who lived in the Bible". In the Old Testament the queen Sheba turns to King Solomon for spiritual enrichment. The simile expresses her state of inferiority as she perceives it. Another example of a biblical reference is the simile; in front of it the long red elevator, like a Jacob's ladder (p.345). It has to do with another biblical character, King Jacob, who dreams of a ladder rising from earth to heaven with angels climbing up and down it. Apart from the religious connotations the object carries, this ladder has often been used as a symbol of something that stretches indefinitely. In the context of the novel it is used as a description of an elevator, a piece of equipment for moving things up and down. Because of its length, it creates an impression of a Jacob's ladder. It is one of several cases where technological innovations are represented by Hardy through expressions 
conveying irony, dislike and lack of trust, which might suggest his aversion to technological progress.

All too often parallels are drawn between characters in the novel and real, historical characters or mythological objects and figures.

...that was only because, like Peter the Great, in a shipwright's yard, he was studying what he wanted to know.

The simile in this case is built on the comparison between Angel Clare and Peter the Great, the Czar of Russia of the end of the $17^{\text {th }}$ and the beginning of the $18^{\text {th }}$ century. According to historical data, Peter the Great was known for his interest in developments of technological-scientific nature. He even supervised the construction of his naval fleet which played a decisive role in the battle against the Ottoman Empire. This is the fact that Hardy refers to when Angel Clare is likened to Peter the Great because, just like him, Clare was in the Talbothays farm to study things with a view to becoming a farmer.

Another instance is the following simile:

...the irregular chalk table-land or plateau bosomed with semi-globular tumuli - as if

Cybele the Many-breasted were supinely extended there...(p.290)

Cybele, a mythical figure considered as the goddess of fertility, has often been represented as a woman with multiple breasts. The simile in the novel is based on the shapes of the relief consisting of hills which bring Cybele's figure to mind.

Some similes contain descriptive components expressed by lexical items belonging to the lexical field of war. Like other expressive means, they are employed for various artistic purposes. For instance, the simile, like an arrow describes the speed at which the mail-cart moves. Its collision with the Derbyfield's cart turns out fatal for the horse. Angel Clare is often represented as a man of principle, someone who uses discretion and does not allow sentiments to shadow his judgment. However, at a certain moment, his feelings for Tess prevail and all his moral scruples are undone just like a defeated battalion. Another detail is that of the glove Tess uses to hit Alec d'Urberville, for which it is said that it was heavy like a warrior's.

There is yet another lexical layer including lexical items that express psychological, mystical, even supernatural phenomena. The dream, as a psychological phenomenon, is used several times as a descriptive element in similes. These similes are present each time the characters experience specific states where words, actions or behaviour are not logically motivated but could be attributed to something unexplainable. The following are some examples:

She obeyed like one in a dream (p.37), "I will - I will," he said, like a man awakening from a luring dream. (p.335), ... and smiled at her disquiet as at a foolish nightmare ( $p .214)$, Tess resumed her position by the buzzing drum as one in a dream...(p.344), She seemed to feel like a fugitive in a dream, who tries to move away, but cannot. (p.394),

Other paranormal phenomena like ghosts and visions are also present.

He was arriving like a ghost...(p.268), ...each damsel was sitting up in her bed awaiting Tess, the whole like a row of ghosts. (p.203), ...he had disappeared like a shape in a vision (p.282)

According to Hardy, the past exerts strong pressure on the present. It seems as if the events in people's lives are predetermined by something mysterious beyond people's control to which they are forced to bow unconditionally. Similes are a typical linguistic expression of this fatalistic philosophy.

...holding only strictly necessary intercourse with the natives, as if some ancient doom compelled him to wander here against his will...(p.337)

\subsection{Translation of similes into Albanian}

\subsubsection{Translation of similes with like}

As pointed out above, similes with like constitute the largest group with 86 instances. Different patterns of translation have been found with regard to the semantic content of the descriptive component. Firstly, there are those that have been translated with their direct Albanian equivalent.

1. .... of this tree that looked like a raging tiger springing from a lair...(f.25) - ...ja kjo pemë i ngjante një tigri të tërbuar qe vërvitet nga strofka...(f.39)

2. ...speeding along these lanes like an arrow...(p.28) - ...kishte kaluar si shigjetë nëpër këto rrugë...(p.43)

3. like a sword, ...(p.28) - si ndonjë shpatë (p.43) 
4. I have been watching you from over the wall - sitting like Impatience on a monument...(p.58) - Po ju vështroja nga muri. Ju qëndroni si statujë e Padurimit mbi statujën e vet...(p.81)

5. I'm like the poor Queen of Sheba who lived in the Bible. (p.129) - Unë jam si ajo mbretëresha e shkretë Saba e biblës! (p.170)

It should be noted that the above and other instances that fall into this category could be considered as literal translations since there is an almost one-to-one correspondence between the elements constituting the English expression and those of the Albanian expression. The similes translated in this way form the majority of the similes with like.

A pattern close to the above is the one in which the English expression and the Albanian expression are quite similar in terms of their semantic content but differ in that the Albanian translation contains one or more additional lexical items which are not present in the English original. The instances which are the closest to literal translations are those featuring the Albanian indefinite pronoun ndonjë (some). For instance:

1. like a map beneath him, (p.6) - si ndonjë hartë gjeografike (p.12) [like some geographical map]

2. like a sword (p.28) - si ndonjë shpatë (p.43) [like some sword]

3. like a geranium bloom against the subdued colours around...(p.33) - si ndonjë elbarozë e kuqe mbi sfondin e ngjyrave të errëta...(p.51) [like some geranium....]

4. like a slimy snake (p.66) - si ndonjë gjarpër zvarritës (p.92) [like some crawling snake]

The Albanian indefinite pronoun ndonjë (some) translates the English indefinite pronoun a. In these cases, the Albanian translator has had two alternatives. One is that with no determiner at all. Because Albanian nouns are marked for (in)definiteness, the translator could have used the noun only leaving out any determiner. The noun itself with its inflection would have been grammatically acceptable. The second is the translation with the Albanian indefinite article një (a/an). However, the translator has opted for the use of ndonjë, which does not change anything in meaning but adds to the degree of indefiniteness. The Albanian translator seems to be quite consistent in this tendency; we have counted at least 11 cases of similes translated with ndonjë.

Another aspect of difference is that of the translation of the comparison marker like with the aid of verbal expressions such as ngjason, (resemble), duket si (look like):

1. eyes like those of a wild animal. (p.52) - sytë e saj të mëdhenj, që dukeshin si sytë e ndonje egërsire. (p.74) [her large eyes, which looked like the eyes of a beast]

2. pain that was like the bitterness of dissolution (p.175) - Me një brengë që $i$ ngjasonte hidhërimit të vdekjes (p.228) [with a pain that resembled dissolution]

3. Jupiter hung like a full-blown jonquil, ...(p.361) - ylli i Jupiterit, që ngjante me ndonjë narcis të verdhë...(p.441) [Jupiter, the star, which resembled a yellow jonquil]

Again the difference is stylistic more than semantic because, as Galperin $(1981,168)$ puts it, similes with like are more straightforward, whereas similes with seem and as if suggest a somewhat more remote resemblance.

The rest of the translations display varying degrees of difference, which, nevertheless, lies mainly in the syntactic aspect of the expression. For instance, various lexical items are added to the Albanian expressions which do not figure in the original expressions:

1. like breezes (p.126) - si një puhizë e lehtë, (p.166) [like a light breeze]

2. like Peter the Great, in a shipwright's yard, ...(p.128) - ...si dikur Pjetri i Madh në kantierin detar...[like Peter the Great once ...]

3. She knew they were waiting like wolves...(p.200) - Ajo e dinte që ... ato fantazma po e përgjonin si ujqër të uritur...(f.258) [...were eavesdropping on her like hungry wolves]

On some occasions similes have been expanded into whole clauses of manner-comparison:

1. ...like a painter from his easel...(p.46) - ...siç bën piktori kur sprapset nga kambaleci...(p.66) [...as a painter does when he steps back from the easel...]

2. ...she seemed to flinch under it like a plant in too burning a sun. (p.174) - ...dhe mblidhej sa një grusht, siç mblidhet bima nën rrezet përcëlluese të diellit. (p.227) [...as the plant flinches in the scorching rays of the sun]

3. Her feelings almost filled her eyes like a babble of waves, ...(p.200) - Dukej sikur ajo i dëgjonte me vesh ndjenjat e saj, siç dëgjohet gurgullima e ëmbël e valëve...(p.257) [....as the sweet gurgle of the waves is heard...] 


\subsubsection{Translation of similes with as}

There are 27 instances of similes with the comparison marker as. On 5 occasions the original similes have been recreated with their correspondents in the Albanian language. Equivalence lies not only in the comparison marker, but in the other constituents as well. Here are three of them:

1. as the tide sways the helpless weed (p.196) - ashtu siç tërheq rrëkeja leshterikët e pafuqishëm, (p. 254)

2. Nightfall, which in the frost of winter comes as a fiend and in the warmth of summer as a lover (p.361) - Në dimrin e ftohtë nata vjen si armik, në verën e ngrohtë vjen si dashnor (p.442)

3. as the voice of the cuckoo in the third week of the same. (p.372) - sa zëri i qyqes në javën e tretë të po atij muaji. (p.455)

On 8 other occasions the similes have been translated not as they appear in the original but rather as whole clauses of manner-comparison with the respective Albanian linguistic means:

1. ...some spirit within her rose automatically as the sap in the twigs. (p.102) - ...shpirti i saj çohej peshë, sikundër çohet peshë lëngu i pemëve. (p.135) [her spirit rose just as the sap in the trees rises]

2. ...began to differentiate themselves as in a chemical process. (p.121) - ...filluan të diferencoheshin, thua se po ndodhte ndonjë proces kimik. (p.159) [began to differentiate as if a chemical process was happening]

3. ....and smiled at her disquiet as at a foolish nightmare? (p.214) - ...siç mund të qeshë njeriu me një makth që nuk ka asnjë bazë? (p.276) [as a man can laugh at a nightmare that has no basis]

4. walking very slowly, without converse, one behind the other, as in a funeral procession, ...(p.240) - ...ecnin shumë ngadalë, pa folur fare dhe njëri prapa tjetrit, sikur po shkonin prapa një qivuri,...(p.304) [...walking very slowly, without talking and one after the other, as if they were walking after a coffin]

We have found three instances in which the simile has not been preserved. This means that the simile has been omitted and has been replaced with a clause with no comparison markers.

1. The snow had followed the birds from the polar basin as a white pillar of a cloud, ...(p.298) - kishte filluar të binte dëborë: ajo binte në formën e një reje të bardhë pluhuri...(p.370) [snow had began to fall: it fell in the form of a white cloud of dust]

2. ...spread into the chilly air as the one soothing thing within the dusky horizon...(p.323) - ...dhe në errësirën e ftohtë, ku nuk depërtonte asgjë, ato zëra tingëllonin në një mënyrë disi qetësuese. (p.403) [...sounded somewhat soothing]

Finally, there are 2 instances in which the meaning has been changed to such a degree that it could be said that they constitute modifications.

1. ...he had come as to a place from which as from a screened alcove he could calmy view the absorbing world without...(p.156) - ...ai kishte pandehur se së këtejmi do të mund të sodiste i qetë (si prej ndonjë skute të mbuluar me perde) botën e jashtme...(p.208) [as from a corner covered with a curtain]

2. ...its more prominent buildings showing as in an isometric drawing. (p.413) - ...me ndërtesa si të pikturave kubiste, ...(f.504) [with buildings like those of the cubist pictures]

\subsubsection{Translation of similes with as ... as}

This type of simile is specific as it is built on three elements. The first is the entity that is being described. The second is an element naming a certain quality which establishes the relationship between the first and the third. The second element is usually an adjective, adverb or other qualitative or quantitative phrase on the basis of which the two entities are compared to each other. The first component does not pose any difficulty in translation. Almost all of the similes within this category have been translated into Albanian with their equivalents. There is only one case that constitutes a shift in the semantic meaning of the original word.

...this feminine tissue (p.74) - shpirti i bukur i kësaj femre (p.102) [the beautiful spirit of this female]

Shifts in the semantic meaning have been found in the translations of the describing components of some of these similes. We shall examine a few of them to illustrate this point.

The stables ...were as dignified as Chapels-of-Ease. (p.34) - Stallat ...ngriheshin madhështore si kisha të vogla (p.51) [The stables ...rose magnificient like small churches]

According to the editor's notes, Chapels-of-Ease were small churches built in remote places to help people carry out their religious rituals conveniently without having to visit the main church of the area. It is obvious that even though the Albanian translation takes up the notion that it is a small church we are dealing with, it misses out on its main semantic feature, which is the social role it plays. It should be said that this is a case of cultural asymmetry. Due to the 
lack of the same notion in the target culture and as a result of a proper word for it, the translator has to make do with what is available to recreate the meaning of the original as best he/she can.

...but he is rotten as touch-wood by now. (p136) - ...tani ka rënë shumë, është katandisur si ndonjë trung $i$ kalbur. (p. 179) [...has been reduced to a rotten log]

This is, in our opinion, a case of ambiguity. The explanation in the editor's notes for this expression is dead. The Albanian translation does not seem to suggest this. It rather emphasizes the state of inability of the person this simile refers to due to old age or sickness.

However, the most striking difference is again syntactic rather than semantic. A common syntactic feature of these similes in the source text is that they function as attributive complements. This means that there is usually a copular verb, be, look, seem that links the descriptor or vehicle to the topic of the simile. This is not the case in the Albanian translation which occasionally employs other means of expression.

1. ...her skin is as sumple as a duchess's. (p.22) - ...e ka cipën të hollë e delikate si ndonjë dukeshë. (p.36) [she has a fine and delicate skin like some duchess]

2. ...her arm was as cold and damp to his mouth as a new-gathered mushroom...(p.180) - ...krahu i Tesit iu duk I ftohtë dhe i lagësht si ndonjë kërpudhë e freskët...(p.233) [Tess's arm seemed to him cold and damp like some fresh mushroom]

\section{Discussion}

Some conclusions could be drawn on the basis of our analysis of the data. Firstly, similes in Hardy's novel Tess of the d'Urbervilles do not present significant difficulty in translation, at least if compared with metaphorical or idiomatic expressions. This is due mainly to the nature of the similes in this novel. As we have pointed out in the section on the semantic features of similes, most of them are built with the aid of universal concepts, which are present in the target culture, which seems to facilitate their translation into the source language. This is in line with van den Broeck's claim about metaphors (1981) that their internationalization will usually lead to a high degree of translatability. This seems to apply to similes too.

The Albanian translations differ from the original expressions not so much in their semantic meaning as in the way they are structured syntactically. Due to their level of semantic simplicity and explicitness, the similes lend themselves well to being translated with their direct equivalents in the target language, Albanian. However, there are cases where shifts are discernible especially in the syntactic aspect. These consist of:

(i) Translation with different comparison markers.

(ii) Addition of one or more lexical items which are not present in the source text and which are not absolutely necessary for the translated text.

(iii) Translation as expressions fulfilling syntactic functions in the clauses where they appear which are different from those the original similes fulfill in the source text.

The consistency of occurrence of the above phenomenon suggests that the translator is mainly concerned with acceptability and naturalness of expression. Even though he stays close semantically to the source text, he allows himself the freedom to work with the phrase and adjust it in order to come up with the variant that will be read most naturally by the Albanian reader.

\section{Conclusions}

In this paper we focused on the similes in Thomas Hardy's Tess of the d'Urbervilles and their translation into Albanian. Our first concern was the creation of a representative research corpus. Because similes are almost always signalled by comparison markers such as like/as/as if/as though/ as...as, their identification and documentation become relatively easy especially if computer programs designed for textual analysis are used. Doing so, we found no less than 160 similes as they appear in the original text. Our main aim was to compare and contrast them with their Albanian translations in order to see what patterns of translation there were and how they were dealt with in this process. The comparison and contrast focused on the similes' semantic and stylistic features related to them. We found that as far as the semantic content is concerned, there are no very great differences between the similes in the source text and their translations. The translator has opted mostly for the obvious options meaning that they have been translated with their direct equivalents in Albanian. This is, we believe, because the similes in Hardy's novel are built on relatively simple and universal notions which are easy to grasp and are present in the Albanian culture. On the other hand, we find that differences lie mostly in the syntactic aspect. The translator consistently manipulates the syntactic structure of the translated expressions first of all 
for variety and secondly for naturalness of expression. For instance, he often inserts words which do not appear in the original. This does not however affect the semantic content of the expression, which remains basically the same. It rather leads to added stylistic effect of the simile. Quite often the translator favours an explicit version of the simile. A third tendency is that of changing the syntactic function of the similes. For example a simile functioning as an attributive complement in the source text is translated as a manner-comparison clause in the target text or vice versa.

\section{References}

Fromilhague, C. (1995) Les figures de style. Paris: Nathan

Galperin, I.R. (1981) Stylistics, Vjsshaja Shkola.

Hardi, T. (2002) Tesi i d'Erbervileve. Tiranë: PEGI.

Hardy, T. (2004). Tess of the d'Urbervilles. London: Bantam Classics.

Harris, R (2013). A Handbook of Rhetorical Devices, London: Virtual Salt.

Newmark, P. (1981) Approaches to Translation. Oxford: Pergamon Press.

Pierini, P. (2007) Simile in English: From Description to Translation. Circulo de Linguistica Aplicada a la Comunicacion (clac) 21-43.

Tsõmbarevitš, A (2011) Translating similes in HarukiMurakami's novel 'Norwegian Wood'.

Master's Thesis. Tallinn University Institute of Germanic and Romance Languages and Cultures Interpreter and Translator Training Center.

Van den Broeck, R. (1981) The Limits of Translatability Exemplified by Metaphor Translation. Poetics Today 2(4) 73-87. 